Article

\title{
Social Behavior and Welfare in Nile Tilapia
}

\author{
Eliane Gonçalves-de-Freitas $1,4, *\left(\mathbb{0}\right.$, Marcela Cesar Bolognesi ${ }^{1,4}$, \\ Ana Carolina dos Santos Gauy ${ }^{1,4}{ }^{(\mathbb{C}}$, Manuela Lombardi Brandão ${ }^{1}{ }^{\mathbb{C}}$, \\ Percilia Cardoso Giaquinto ${ }^{2,4}$ (D) and Marisa Fernandes-Castilho ${ }^{3,4}$
}

1 Departamento de Zoologia e Botânica, Universidade Estadual Paulista (UNESP), Rua Cristóvão Colombo 2265, São José do Rio Preto, SP 15054-000, Brazil; marcelacbolognesi@gmail.com (M.C.B.); ana.gauy@gmail.com (A.C.d.S.G.); manulbrandao@gmail.com (M.L.B.)

2 Departamento de Fisiologia, Instituto de Biociências, Universidade Estadual Paulista (UNESP), Rua Professor Dr. Antonio Celso Wagner Zanin S/N., Botucatu, SP 18618-689, Brazil; percilia.giaquinto@unesp.br

3 Departamento de Fisiologia, Setor de Ciências Biológicas, Universidade Federal do Paraná (UFPR), Av. Coronel Francisco H. dos Santos 100, Curitiba, PR 81531-970, Brazil; mafernandes@ufpr.br

4 Centro de Aquicultura da UNESP, Jaboticabal, SP 14884-900, Brazil

* Correspondence: eliane.g.freitas@unesp.br; Tel.: +55-17-3221-2375

Received: 7 February 2019; Accepted: 12 March 2019; Published: 27 March 2019 updates

\begin{abstract}
Fish social behavior can be affected by artificial environments, particularly by factors that act upon species that show aggressive behavior to set social rank hierarchy. Although aggressive interactions are part of the natural behavior in fish, if constant and intense, such interactions can cause severe body injuries, increase energy expenditure, and lead the animals to suffer from social stress. The immediate consequence of these factors is a reduced welfare in social fish species. In this paper, we consider the factors that impact on the social behavior and welfare of Nile tilapia, an African cichlid fish widely used both in fish farms and in research; this species is frequently used as a model for physiology and behavior research. This is a polygynous species whose males interact aggressively, establishing a territorial based hierarchy, where a dominant male and several subordinate males arise. When social stability is shrunk, the negative effects of prolonged fighting emerge. In this paper, we summarized how some of the common practices in aquaculture, such as classifying individuals by matching their sizes, water renewal, stock density, and environment lighting affect Nile tilapia social aggressive interactions and, in turn, impact on its welfare. We also discuss some ways to decrease the effects of aggressive interactions in Nile tilapia, such as environment color and body tactile stimulation.
\end{abstract}

Keywords: aggressive interaction; social stress; fighting ability; social rank; social communication

\section{Introduction}

Social behavior is defined as any kind of interaction between conspecifics, in such a way that it influences their immediate or future behavior [1]. In this conceptual framework, fish social behavior includes reproductive behavior, such as mating and courtship, cooperative interactions [2,3], shoaling [4], and social hierarchy, which is marked by aggressive interactions to reach a certain social rank and to defend territory, as well as environmental resources [5]. Social interaction, however, is not limited to conspecifics, but it can also occur among heterospecifics, such as in client-cleaner coral reef fishes, wherein a species cooperates by cleaning parasites off of another species, thus interacting between them $[6,7]$.

For each kind of social interaction, several types of information are exchanged between interactants, either directly or indirectly. In the first and more generalized case, information is 
exchanged between interactants, for instance, during contests to achieve a dominant rank [8]. In the second one, an individual gathers information indirectly from other interactants, and uses that information at a later time, in a similar circumstance. For example, a male Betta splendens will quickly engage in a contest after obtaining information about its rival's fighting outcome if it is a loser, but will approach more slowly if facing a winner from a previous fight [9]. Thus, socially organized individuals receive and send several types of messages from/to conspecifics, within a social communication network; it is interpreted depending on several intrinsic and extrinsic factors. When the external environment is changed, social communication can be impaired and social interactions can be affected. For instance, for some fish species chemical information is important in social rank communication [10], however, water dilution can dilute such information, thus, disturbing social stability and increasing aggressive interactions [11,12].

According to Creel et al. [13], social environment is one of the main sources that induces physiological stress in vertebrates, known as social stress. The type of interaction alongside the social rank stimulates the hypothalamic-pituitary-adrenal (HPA) axis, thus increasing the secretion of glucocorticoids, which will impact upon the growth, reproduction, and immune function of animals [13]. Cortisol levels, for instance, are higher for dominant or subordinate individuals, depending on the circumstances [13]. Social instability, in turn, is usually associated to increased stress and its negative effects upon individuals $[14,15]$, as that is a condition characterized by intense and prolonged fighting; therefore, knowing the factors that affect social behavior is an important tool to understand the mechanisms modulating animal welfare.

A rich behavioral repertoire is shown by fish species from the cichlid group, whose social behavior is complex and, although some variations can occur, it does have some patterns as a species. For example, all cichlid species take care of their broods, which can be defined as a bi-parental care, with both the male and the female caring for the eggs and fingerlings in the substrate [16]; or mono-parental care, with only the male or the female taking care of eggs by keeping the fingerlings inside their mouths (mouthbrooding cichlids) [17]. Some species show cooperative behavior as helpers in the group [3]. Despite these behavioral variations, all cichlid species engage in aggressive interactions to establish social rank and territory [16], which is marked by biting, mouth fighting, tail beating (known as overt fight), and by signals such as threats and other displays (restrained aggression). This type of interaction is not only observed in adult males and females, but also in juveniles, which show a very similar aggressive behavior to that of adults. For example, the angelfish Pterophylum scalare and the Cichlasoma parananese show a similar social interaction, their social rank being clearly established when they are juveniles [12,18]. Aggressive behavior is, therefore, part of the competition for resources, for example, food, reproductive partners, spawning and brood care site, in which dominant individuals have priority over others to access such resources [19]. Overall, the adaptive value of such social hierarchy is to reduce the detrimental effects of competition, by organizing the access to environmental resources and reducing the cost of prolonged fighting, such as energy expenditure, body injuries, and social stress for the contestants.

Although aggressive interactions are part of their natural behavior, some of the common practices in aquaculture, such as classifying individuals by matching their size, water renewal, stock density, and environment lighting can affect social interactions in a way that shrinks the natural adaptive value of social behavior. As a consequence, there will be reduced welfare in social fish species, as well as an impact on fish production [5]. In this paper, we present a synthesis on social impairment and welfare of Nile tilapia, Oreochromis niloticus (Linnaeus, 1758), an African cichlid fish widely used both in fish farms and as a research model due to its physiology and behavior. In fact, tilapia production has grown exponentially over the last few years (global production was approximately 5.6 million tons in 2015, [20]) and it has become the second most farmed fish species worldwide [20]. Thus, it is necessary to consider factors affecting the species' welfare to propose adequate technology for the improvement of tilapia farming and housing. 


\section{Nile Tilapia Social Behavior}

Nile tilapia is a polygynous species whose male individuals aggressively interact establishing a territorially based hierarchy [21]. The contestant males fight each other, a winner emerges (dominant male) and starts to defend a territory wherein a circular nest is dug and courtship and spawning will take place [22,23]. Many subordinate males defend territories near the dominant one, although some males do not get any territory at all. Mating occurs through a lek system, with females visiting several nests before mating (Figure 1). After spawning, females take the eggs in their mouths and carry out mouthbrooding for nearly 14 days, until broods are completely released in the open environment [21].

Similarly to other cichlids, Nile tilapia adult males and females show social-rank based interactions [24,25]. Juveniles also have a similar behavior to that of adults (e.g., [26,27]), however, it is probably due to a competition for food rather than for reproduction [28]. Depending on the context, social rank is kept among males through physical limits on the ground (territory and nest), as well as through different types of sensorial cues, such as visual [29,30], chemical [31], and acoustic ones [32,33] which counteract overt fights. When some of these social signs are impaired by environmental changes, specifically artificial ones, social rank signals become unable to keep social stability, thus increasing the negative effects of prolonged fighting, such as increased social stress and decreased growth, which are indicated and discussed hereafter.

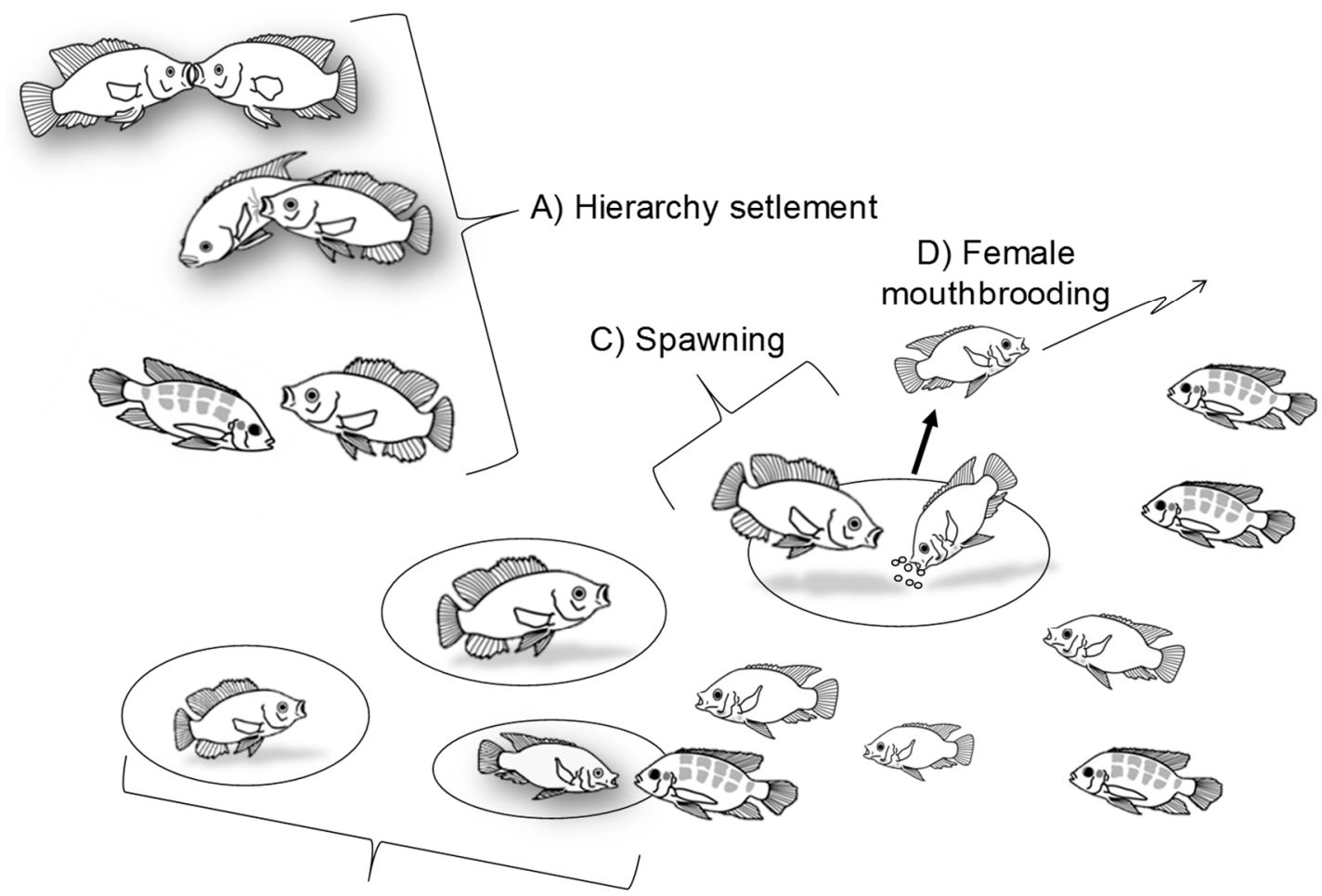

B) Nesting and territorial defense

Figure 1. Nile tilapia's social behavior. Males fight (A) and a dominant and subordinate rank (clear and gray fish, respectively) emerge; the dominant male starts to defend a territory, wherein it digs a circular nest (B). The mating system is a lek polygyny; then several males dig nests surrounding dominants (B). Fish continue defending territory and attracting females (C). After spawning, the female leaves the arena and starts mouthbrooding until fryers arise (D). Some males do not get territory and stay around the arena challenging territorial males (some act as sneakers). Females (the smallest fish in the drawing) visit the arena and mate with territorial males.

\section{Social Stress and Socially Controlled Growth}

The stress caused by the social organization of animals is an inherent biological characteristic to many animal species, with representative examples on fish and other vertebrate classes [13]. For these 
species, different social statuses in a group will impinge different demands on individuals and, therefore, different amounts of energy availability resulting in fish with different growth rates and developments, including reproduction. Nile tilapia is one of these species, whose causal factors of intraspecific growth heterogeneity were extensively investigated by our research group, at the time led by Dr. Gilson Volpato, as shown hereafter.

Although results varied genetically for individuals with different growth rates, we observed that the growth heterogeneity in Nile tilapia is associated with the social rank of the animals in the group; i.e., dominant animals grow more than subordinate ones [34]. Volpato and Fernandes [35] proposed a diagrammatic view of the mechanisms involved in the social control of growth in fish, considering species that present or do not present a hierarchical rank. According to them, the heterogeneous growth found in socially organized fish may be due to a combination of the following factors related to social stress: different food intake rates (paradigm of food competition), different digestion rates, appetite suppression, or different rates of energy expenditure of animals occupying different social statuses in the group (paradigm of social stress). Studies conducted in our laboratory suggest that dominant and subordinate Nile tilapia individuals eat equivalent amounts when food is not a limited resource, with a temporal difference in intake; dominant animals eat before subordinate ones $[35,36]$. The stress arising from the social hierarchy of dominance is considered to be the main promoter of growth heterogeneity in Nile tilapia. Subordinate individuals show higher metabolic rates than dominant ones, thus indicating that most of the energy is used for other purposes. Studies developed by Fernandes and Volpato [37] on the effect of social stress on carbohydrate metabolism in adult Nile tilapia were pioneers in demonstrating that subordinate animals had a glycemic concentration that was twice as high as dominant ones after two days of grouping, and had a significant decrease in hepatic glycogen concentration after four days, which indicates that subordinates use more energy for adjustment to social stress than dominants.

Metabolic differences between fingerlings from different social ranks were also demonstrated by Alvarenga and Volpato [27], when they found a significant association between some agonistic profiles and metabolism in juvenile Nile tilapia, inferred from oxygen consumption, resistance to progressive hypoxia, and ventilatory rate. The authors pointed out that the metabolic variability among individuals of the same social status is directly related to the agonistic profile of male interactants. Then, the individual growth rate in Nile tilapia results from the individual metabolic pattern impinged by the stress caused by the social hierarchical status. Subordinates grow less than dominants, in a linear scale, according to their social rank.

Recently, de Verdal et al. [28] found no correlation between social rank, food conversion efficiency, and growth rates in juvenile Nile tilapia. The authors concluded that such a result could be explained by a low number of agonistic interactions and the fact that fish were under low food competition. However, according to Carrieri and Volpato [36], the snatching frequency is not a reliable parameter to indicate an individual food intake among Nile tilapia, which problematizes studies that require the evaluation of the cumulative effect of competition on food intake, such as growth or conversion efficiency studies. On the other hand, de Verdal et al. [28] studied groups of 15 individuals, which suggests that social hierarchy could be affected by the number of animals interacting in the group.

\section{Impacts on Social Rank-Based Behavior}

\subsection{Body Size and Fighting Abilities}

An important cue related to social information is the access to the opponent's fighting abilities [38]. In this sense, body size constitutes crucial information, as several cichlid species can visually access this characteristic in their opponents (see [39], for Melanochromis auratus, and [40] for Astronotus ocellatus). The more similar the size, the longer and harder the fighting, as shown for Nannacara anomala [41]. Despite this knowledge, fish like Nile tilapia are selected according to their similar size during grading management in aquaculture systems [42], which results in fish with similar fighting abilities being in 
the same tank. This method can increase chances of mortality as a consequence of massive energy expenditure and also of physical injuries. In fact, this is the case with Nile tilapia. Boscolo et al. [43] studied the effect of matching Nile tilapia males, GIFT lineage, according to their size. They compared aggressive interactions in groups formed by five homogeneously sized or heterogeneously sized males. They found that fish had twice as many fights in the homogeneous group compared to the heterogeneous one; they also showed social instability, although the cortisol level was similar in both treatments. Furthermore, Barreto et al. [44], found a similar result for Nile tilapia, Thai lineage, in which fish showed increased body lesions and scales loss when grouped according to their size. In this case, cortisol was equally elevated for every individual in the similar-sized group, whereas it was high only for alpha and beta fish in the heterogeneous group. Altogether, these studies clearly demonstrate the negative impact of gathering fish with similar sizes (and similar fighting abilities) on the Nile tilapia welfare. As an example, Garcia et al. [45] found a higher growth performance for Nile tilapia in tanks where no size selection was applied. Thus, the heterogeneous growth originated from social rank system seems to be an adaptive mechanism for reducing overt fights in Nile tilapia, indicating that grading should be rethought.

\subsection{Stocking Density}

Stocking density, strictu sensu, is the concentration at which fish are initially stocked into a system, but the term has been used to refer to the density of fish at any point in time, considering either their biomass or the number of fish [46]. The stocking density is directly linked to welfare as it affects food competition and consumption, growth, stress, health, and mortality [46]. For social species, the number of individuals in a group is associated to the probability of encounters. As a result, we would expect that the larger the group is, the higher the probability of fighting. However, the contrary is observed for other species, such as salmonids, whose aggressive interactions reduce at high stocking densities [46,47].

There are several studies regarding the effects of stocking density on the Nile tilapia production, but only a few suggesting the effects of social behavior, although they do not quantify aggressive interactions. For instance, according to Ellison et al. [48], Nile tilapia reared at low stocking densities (fry $\mathrm{LD}=94$ individuals at $1.5 \mathrm{~kg} \mathrm{~m}^{-3}$ vs. fry $\mathrm{HD}=366$ individuals at $6 \mathrm{~kg} \mathrm{~m}^{-3}$ ) have an increased expression of genes related to stress which is likely due to increased aggressive interactions; moreover, they are more susceptible to the consequences of infection by Saprolegnia parasitica, and have higher mortality rates. Overall, these authors showed that Nile tilapia reared at low densities have a higher susceptibility to negative effects than those reared at higher densities. On the other hand, Garcia et al. [45] showed that a low stocking density (130 juveniles $\mathrm{m}^{-3}$ vs. 450 juveniles $\mathrm{m}^{-3}$ ) improves growth rate and food conversion in Nile tilapia. Among several factors, the authors discussed the probability of a better opportunity for both subordinate and dominant fish to access food and to reduce aggressive interactions among them. Barcellos et al. [49] studied the Nile tilapia's response to an acute stressor (net chasing) at four stocking densities (groups of one, two, five, and $10 \mathrm{fish} / 100 \mathrm{~L}^{-1}$ ). They found higher cortisol levels at stocking densities of 10 fish compared to those of one, two, and five. They attributed these results to detrimental effects from social stress, which was probably caused by agonistic interactions. Although these three studies discuss the effects of social behavior on Nile tilapia's performance under different stock densities, none of them quantified their social interactions. Indeed, the number of animals clearly hinders the aggressive behavior quantification for most of those conditions. Furthermore, there are differences in the experimental protocol between those studies that make it difficult to conclude only in terms of high or low density if social hierarchy can be affected by the number of animals in the group, without considering the amount of available food, shelter, and space [5]. Nevertheless, studies combining the effect of stocking density and social aggressive interactions should be conducted in order to allow us a better understanding of its impact on Nile tilapia's welfare. 


\subsection{Chemical Communication and Social Rank Signaling}

Cichlids are known to use chemical information in several social interactions, particularly when signaling social rank, as in Astatotilapia burtoni [50], for example. In fact, differences between dominants and subordinates have been shown for the well-studied species Mozambique tilapia Oreochromis mossambicus [10,51], whose male stores urine and releases it when a male intruder invades its territory [52]. Furthermore, males reduce their aggressiveness against a mirror when exposed to the urine of a dominant male [53], showing that urinary odorants act as a dominance signal for this species, modulating the aggressiveness in rival males and keeping the social hierarchy stable.

The chemical communication is also important for the social behavior of this species. The first authors to show the role of chemical communication in Nile tilapia were Giaquinto and Volpato [31]. They observed that the recognition of social positions for such species was impaired when chemical communication was absent, even when there was visual contact. Male pairs were kept in an aquarium and were separated by a transparent glass (so that they had visual contact) with a hole in it, allowing water to flow between compartments. When the hole was capped and chemical communication was interrupted, fish spent more time fighting and hierarchy was not established. These results showed that chemical cues can play an important role in Nile tilapia's dominance relationships. Later, Gonçalves-de-Freitas et al. [11] simulated a scenario of water changing, a common practice in fish maintenance. They tested the effect of water renewal on aggressive interactions between pairs of juvenile male Nile tilapia, and found that after $50 \%$ water changing, subordinate fish started to fight dominant ones again, destabilizing social hierarchy. This showed that chemicals which signalized dominance had been washed out through water renewal, stimulating fights in the group [11]. How, then, could we control the water quality without washing away important social signals? The answer could be the amount of water renewed. In the juvenile angelfish cichlid, Pterophyllum scalare, for example, a change of $25 \%$ water stimulated aggressive interactions in the group for one hour, and after this period aggressive interactions returned to basal levels [12]. On the other hand, after changing 50\% water, fish kept an increased aggressive interaction rate for $24 \mathrm{~h} \mathrm{[12].}$ Thus, it is possible that other cichlid species, such as Nile tilapia, also behave that way, although this hypothesis needs to be tested.

\subsection{Environment Lighting}

Changes in environment lighting can affect aggressive interactions and stress in fish by increasing light intensity [54] or by changing the daily photoperiod [55]. These effects are usually indirect, since they change the levels of melatonin in individuals, which is a light-controlled hormone involved in the modulation of several types of behavior, such as biological rhythm, color change, and aggressiveness [56]. High levels of melatonin are associated to reduced aggressive behaviors in fish and other vertebrates, whereas the opposite is also true, i.e., reduced melatonin is associated with increased aggressive behaviors [57-60]. Thus, long days and high intensity illumination are expected to increase aggressiveness, although some differences can be found among fish species and developmental stages. Environment lighting is a matter of consideration for the Nile tilapia welfare, because they have a good sense of vision [61,62]; consequently, light can affect their behavior and physiology in several ways. These factors are, however, more relevant in aquaria systems, inside laboratories, where the environment is more translucent than in ponds.

In Nile tilapia, increased light intensity (from 280 to 1390 lx) reduces aggressive interactions between pairs of juvenile males [63], whereas it clearly increases fights among adult males [64]. Although it is known that cichlids are more aggressive and tend to become dominant under long photoperiods, such as Cichlasoma dimerus [65] and Tilapia rendalli [55], information about this influence on Nile tilapia's social behavior is scarce in the literature. According to Martinez-Chavez et al. [66], Nile tilapia shows a daily variation in melatonin levels, which follows a clock-controlled rhythm (low during photophase and high during scotophase); it allows us to hypothesize that the day length can affect social aggressive interactions as it happens for other cichlids. Studies regarding the effect of 
day length on Nile tilapia is related to other important parameters to aquaculture purposes, such as feeding rate, growth, and reproduction [67]. Thus, the effect of day length on aggressive interactions of Nile tilapia is still an open research field.

\section{Mitigation Technics}

A way to reduce the detrimental effects of fish fights is, obviously, to know what increases aggressive encounters and, then, shape the artificial environment accordingly. For example, finding ways to keep low intensity illumination in translucent environments, renewing a lower amount of water from the tanks, or avoiding grouping fish with similar fighting abilities (same sized fish) in the same place. Knowledge on some of these mitigating factors is still scarce or confused, such as stocking density. Therefore, it is obviously necessary to keep studying in order to find out how external environment and management practices affect the social behavior of Nile tilapia. However, there are some other strategies that can help reduce aggressive interactions. We will now discuss some of them.

\subsection{Environmental Enrichment}

The first solution we can arrive at in order to improve Nile tilapia's welfare is providing them with a more enriched environment. As a definition, environmental enrichment is a modification of the environment, which may increase the animals' behavioral opportunities and lead to improvements in their biological function [68]. Enrichment offers new opportunities to express behaviors and to achieve preferred activities by animals $[69,70]$. In addition, it may reduce abnormal behaviors, such as stereotypies [69].

Some studies with fish had already shown that environmental enrichment can reduce the behavioral deficit in poor artificial environments [71-73]. It was also demonstrated that enrichment decreases aggression rates between individuals in zebra fish (Danio rerio) [74], in the convict cichlid (Archocentrus nigrofasciatus, redescribed as Amatitlania nigrofasciata) [75], in the pearl cichlid (Geophagus brasiliensis) [76], and in the redbreast tilapia (Tilapia rendalli) [77]. These authors discuss that an enriched and more complex environment may decrease the probability of encounters between animals, by reducing the visibility between opponents or limiting the boundaries of small territories in the environment, leading to a decrease in aggressive interactions in these species. However, the opposite occurs for Nile tilapia. According to Barreto et al. [78], environmental enrichment increases the aggressiveness in Nile tilapia males. Such an effect occurs because enrichment increases the value of the resource (territory). Thus, individuals are more aggressive when striving for valuable resources to themselves. In fact, the cost of fight can increase as the resource value increases [79]. Therefore, environmental enrichment is not a way to counteract aggressive interactions in Nile tilapia, and would reduce welfare instead.

\subsection{Body Tactile Stimulation}

Tactile stimulation is achieved through a mechanical stimulus, such as touches on the body, when two or more individuals are interacting [80], or artificially, by using some devices [81,82]. Such stimulation has been studied as an alternative to promote animal welfare in several animal groups. In mammals, for example, tactile stimulation reduces both stress levels [83] and heart beat rates [84]. Soares et al [81] demonstrated that tactile stimulation decreases stress in a coral reef fish, decreasing its cortisol levels after confinement. However, Bolognesi et al. [82] demonstrated that tactile stimulation does not decrease the cortisol level in Nile tilapia immediately after the application of a stressor (either social or non-social stressor), but it reduces the aggressiveness in pair staged fights. Such an effect was supposed to be controlled by serotonin (5HT), since this neurotransmitter is released during body tactile stimulation and acts as an inhibitor of aggression in fish $[85,86]$. This present study raises the potential of using tactile stimulation as a way to mitigate the negative effects of social aggressive interactions on Nile tilapia and other fish species. 


\subsection{Environment Color}

Fish have photoreceptor cones in their eyes, which give them color vision $[87,88]$, and allow them to discriminate between different colors in the environment [89]. The most common methods for studying the effects of the colors of the environment are through testing different background colors [90] or applying colors to the environment [91]. A red environment, for example, stimulates food intake but not growth [92], whereas a blue environment is efficient to improve reproduction in Nile tilapia [93]. Additionally, a blue environment influences Nile tilapia's HPI axis, since isolated fish show lower cortisol levels after a confinement stress [94]. Maia and Volpato [91] also demonstrated that a blue lighted environment prevents the increase in the ventilatory frequency in confined fish. Although how the color of the environment will affect Nile tilapia's social aggressive behavior is not available in the literature, we assume that this could be a way to reduce the detrimental effects of aggressive interactions, since the blue color reduces stress levels in Nile tilapia.

\subsection{Preference Tests}

Naturally Nile tilapia's welfare is not limited to their social aggressive behavior. Even though it is not so easy to reduce this inherent individual stressor, it is possible to adopt several measures upon fish behavior. Preference tests, for instance, are widely used to promote better animal welfare; through them, we know what an animal wants regardless of physiological indicators [95-97]. By knowing what animals prefer, we can shape the environment by providing the preferred items and therefore, increase the fish welfare level. However, preference tests should be carried out under several conditions, taking into account successive choices among several items, and keeping in mind that preference may vary from individual to individual and over time $[89,95])$.

Some preference tests were carried out with Nile tilapia over the last years. For example, Luchiari et al. [98] demonstrated that individuals prefer to access places lit by yellow light rather than red, green, blue, or white light. However, a recent study conducted by Maia and Volpato [99] showed that it takes at least 10 days of testing to find the color preference for this species, green and blue being the most preferred colors in the population. Another study assessing the motivation of Nile tilapia to access places with distinct colors also showed that they were less motivated to access yellow and red, but were more motivated to access green and blue [89]. Few individuals prefer yellow, which reinforces individual preference in such tests [89].

Mendonça et al. [100] showed that Nile tilapia males chose to make their nests in sand substrate when compared to other substrates such as stones; this indicates that the weight and structure of the substrate is evaluated by fish. Furthermore, Freitas and Volpato [101] tested different substrates granulometry and also demonstrated that tilapia individuals prefer small-grained substrates. This preference was more consistent during the morning period than the afternoon, proving the relevance of the period of the day. As we can see, preference tests are still scarce to evaluate Nile tilapia welfare. Further research is needed to understand how preferences could be associated to aggressive interactions and if such preferences are capable of reducing their consequent detrimental effects.

\section{Concluding Remarks}

Several studies regarding the welfare in Nile tilapia consider growth, stress, and reproduction. However, some of the problems found in aquaculture and the welfare of tilapia are, in fact, consequences of their social interactions. It is necessary to keep in mind that social aggressive interactions depend on the external environment, as well as on fish communication, and social environment, which includes information and response from other individuals in a group (Figure 2). 


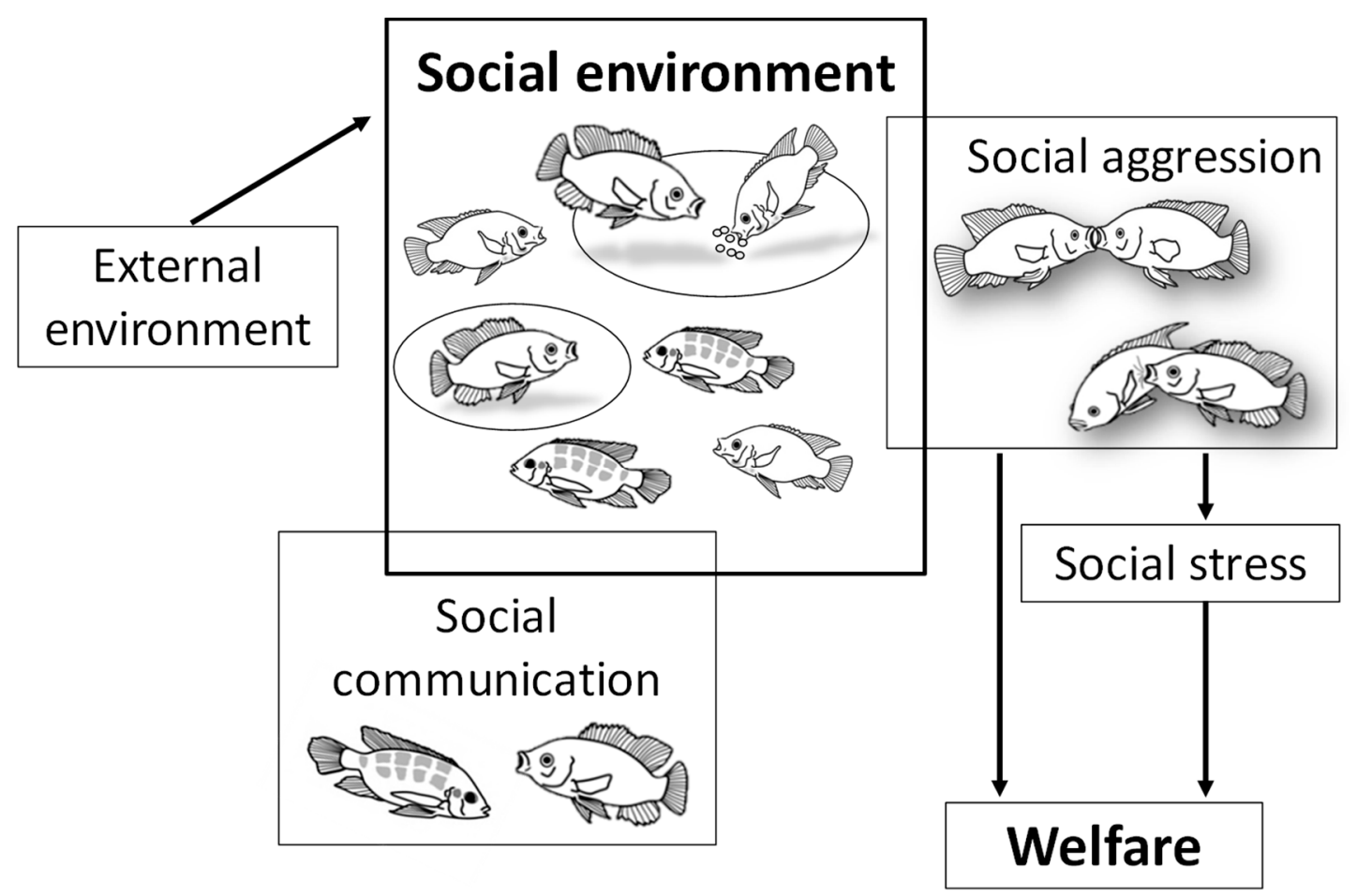

Figure 2. Summary of factors in artificial environment that would affect Nile tilapia's social behavior. For instance, light intensity, color, water renewal, grading for size, stocking density, and any other management that directly affects social communication. When such changes increase aggressive interactions, the welfare will be impaired by increased social stress levels and other effects from fighting, such as body injuries and very high energy expenditure. In summary, everything that affects social environment will affect welfare as well.

What is necessary therefore to know about social behavior in order to deal with Nile tilapia welfare? The main points are listed here:

1. Knowing communication channels and their role as social signaling to keep a good environment for social communication. Lack of information on social rank will increase aggressive interactions.

2. The dynamics of social interaction, including information regarding the adaptive value of such behavior (e.g., fighting ability). In this sense, grading to gather same sized fish will group together individuals with the same fighting abilities. The consequence will be increased aggressions and, certainly, mortality will be higher than that already considered during fish management.

3. Factors affecting aggressiveness (such as environment lighting and color) and physiological control, both neural and hormonal, of individual aggressiveness. Adequate control on such variables will help not to exaggerate the effects from aggressiveness.

4. Strategies to counteract aggressive behaviors, such as body tactile stimulation, which will increase welfare and health in several ways. This is still a developing possibility for fish keeping and aquaculture.

Author Contributions: E.G.-d.-F. conceived the idea for the revision and organized the topics to be covered. Since this article is a review, all authors contributed by providing data information, writing and critically reading the content. All authors agree with the ideas and conclusions herein.

Funding: EGF research is supported by the "National Council of Technological and Scientific Development"-CNPq (\# 310648/2016-5).

Acknowledgments: We acknowledge the main person responsible for these 30 years of history regarding Nile tilapia behavior and welfare: Gilson L. Volpato-now at IGVEC (Gilson Volpato's Institute for Scientific Education).

Conflicts of Interest: There is no conflict of interest. 


\section{References}

1. Robinson, G.E.; Fernald, R.D.; Clayton, D.F. Genes and Social Behavior. Science 2008, 322, 896-900. [CrossRef]

2. Teresa, F.B.; Gonçalves-de-Freitas, E. Reproductive Behavior and Parental Roles of the Cichlid Fish Laetacara araguaiae. Neotrop. Ichthyol. 2011, 9, 355-362. [CrossRef]

3. Tanaka, H.; Frommen, J.G.; Koblmüller, S.; Sefc, K.M.; McGee, M.; Kohda, M.; Awata, S.; Hori, M.; Taborsky, M. Evolutionary Transitions to Cooperative Societies in Fishes Revisited. Ethology 2018, 124, 777-789. [CrossRef]

4. Kasumyan, A.O.; Pavlov, D.S. Evolution of Schooling Behavior in Fish. J. Ichthyol. 2018, 58, 670-678. [CrossRef]

5. Damsgård, B.; Huntingford, F. Fighting and Aggression. In Aquaculture and Behavior; Huntingford, F., Jobling, M., Kadri, S., Eds.; Wiley-Blackwell: Oxford, UK, 2012; p. 340.

6. Paula, J.R.; Messias, J.P.; Grutter, A.S.; Bshary, R.; Soares, M.C. The Role of Serotonin in the Modulation of Cooperative Behavior. Behav. Ecol. 2015, 26, 1005-1012. [CrossRef]

7. Triki, Z.; Bshary, R.; Grutter, A.S.; Ros, A.F.H. The Arginine-Vasotocin and Serotonergic Systems Affect Interspecific Social Behaviour of Client Fish in Marine Cleaning Mutualism. Physiol. Behav. 2017, 174, 136-143. [CrossRef]

8. Desjardins, J.K.; Fernald, R.D. How Do Social Dominance and Social Information Influence Reproduction and the Brain? Integr. Comp. Biol. 2008, 48, 596-603. [CrossRef] [PubMed]

9. Oliveira, R.F.; McGregor, P.K.; Latruffe, C. Know Thine Enemy: Fighting Fish Gather Information from Observing Conspecific Interactions. Proc. R. Soc. B Biol. Sci. 1998, 265, 1045-1049. [CrossRef]

10. Keller-Costa, T.; Canário, A.V.M.; Hubbard, P.C. Chemical Communication in Cichlids: A Mini-Review. Gen. Comp. Endocrinol. 2015, 221, 64-74. [CrossRef] [PubMed]

11. Gonçalves-de-Freitas, E.; Teresa, F.B.; Gomes, F.S.; Giaquinto, P.C. Effect of Water Renewal on Dominance Hierarchy of Juvenile Nile Tilapia. Appl. Anim. Behav. Sci. 2008, 112, 187-195. [CrossRef]

12. dos Santos Gauy, A.C.; Boscolo, C.N.P.; Gonçalves-de-Freitas, E. Less Water Renewal Reduces Effects on Social Aggression of the Cichlid Pterophyllum scalare. Appl. Anim. Behav. Sci. 2018, 198, 121-126. [CrossRef]

13. Creel, S.; Dantzer, B.; Goymann, W.; Rubenstein, D.R. The Ecology of Stress: Effects of the Social Environment. Funct. Ecol. 2013, 27, 66-80. [CrossRef]

14. Sapolsky, R.M. Cortisol Concentrations and the Social Significance of Rank Instability among Wild Baboons. Psychoneuroendocrinology 1992, 17, 701-709. [CrossRef]

15. Carvalho, R.R.; Palme, R.; da Silva Vasconcellos, A. An Integrated Analysis of Social Stress in Laying Hens: The Interaction between Physiology, Behaviour, and Hierarchy. Behav. Processes 2018, 149, 43-51. [CrossRef] [PubMed]

16. Barlow, G. The Cichlid Fishes: Nature's Grand Experiment in Evolution, 1st ed.; Basic Books: New York, NY, USA, 2002.

17. Balshine, S.; Sloman, K. Parental Care in Fishes. In Encyclopedia of Fish Physiology: From Genome to Environment; Farrel, A.P., Ed.; Academic Press: San Diego, CA, USA, 2011; Volume 1, pp. 670-677.

18. Brandão, M.L.; Colognesi, G.; Bolognesi, M.C.; Costa-Ferreira, R.S.; Carvalho, T.B.; Gonçalves-de-Freitas, E. Water Temperature Affects Aggressive Interactions in a Neotropical Cichlid Fish. Neotrop. Ichthyol. 2018, 16, 1-8. [CrossRef]

19. Huntingford, F.A.; Turner, A.K. (Eds.) Animal Conflict; Springer: Dordrecht, The Netherlands, 1987. [CrossRef]

20. FAO. World Aquaculture 2015: A Brief Overview; FAO: Rome, Italy, 2017; Volume 1140.

21. Lowe-McConnell, R.H. Observations on the Biology of Tilapia nilotica Linné in East African Waters. Rev. Zool. Bot. Afr. 1958, 57, 129-170.

22. Gonçalves-de-Freitas, E.; Nishida, S.M. Sneaking Behavior of the Nile Tilapia. Bol. Técnico CEPTA 1998, 11, 71-79.

23. Mendonça, F.Z.; Gonçalves-de-Freitas, E. Nest Deprivation and Mating Success in Nile Tilapia (Teleostei: Cichlidae). Rev. Bras. Zool. 2008, 25, 413-418. [CrossRef]

24. Carvalho, T.; Gonçalves-de-Freitas, E. Sex Group Composition, Social Interaction, and Metabolism in the Fish Nile Tilapia. Braz. J. Biol. 2008, 68, 807-812. [CrossRef] 
25. Gonçalves-de-freitas, E.; Ferreira, A.C.; Paulista, U.E.; José, S. Female Social Dominance Does Not Establish Mating Priority in Nile Tilapia. Etologia 2004, 6, 33-37.

26. Pinho-Neto, C.F.; Miyai, C.A.; Sanches, F.H.C.; Giaquinto, P.C.; Delicio, H.C.; Barcellos, L.J.G.; Volpato, G.L.; Barreto, R.E. Does Sex Influence Intraspecific Aggression and Dominance in Nile Tilapia Juveniles? Behav. Process. 2014, 105, 15-18. [CrossRef] [PubMed]

27. Alvarenga, C.M.D.; Volpato, G.L. Agonistic Profile and Metabolism in Alevins of the Nile Tilapia. Physiol. Behav. 1995, 57, 75-80. [CrossRef]

28. de Verdal, H.; O’Connell, C.M.; Mekkawy, W.; Vandeputte, M.; Chatain, B.; Bégout, M.-L.; Benzie, J.A.H. Agonistic Behaviour and Feed Efficiency in Juvenile Nile Tilapia Oreochromis niloticus. Aquaculture 2019, 505, 271-279. [CrossRef]

29. Falter, U. Description of the Color Patterns in Oreochromis niloticus (L) (Teleostei, Cichlidae). Ann. Soc. R. Zool. Belgique 1987, 117, 201-219.

30. Volpato, G.L.; Luchiari, A.C.; Duarte, C.R.A.; Barreto, R.E.; Ramanzini, G.C. Eye Color as an Indicator of Social Rank in the Fish Nile Tilapia. Braz. J. Med. Biol. Res. 2003, 36, 1659-1663. [CrossRef] [PubMed]

31. Giaquinto, P.C.; Volpato, G.L. Chemical Communication, Aggression, and Conspecific Recognition in the Fish Nile Tilapia. Physiol. Behav. 1997, 62, 1333-1338. [CrossRef]

32. Longrie, N.; Poncin, P.; Denoël, M.; Gennotte, V.; Delcourt, J.; Parmentier, E. Behaviours Associated with Acoustic Communication in Nile Tilapia (Oreochromis niloticus). PLoS ONE 2013, 8, e61467. [CrossRef] [PubMed]

33. Longrie, N.; Van Wassenbergh, S.; Vandewalle, P.; Mauguit, Q.; Parmentier, E. Potential Mechanism of Sound Production in Oreochromis niloticus (Cichlidae). J. Exp. Biol. 2009, 212, 3395-3402. [CrossRef]

34. Volpato, G.L.; Frioli, P.M.A.; Carrieri, M.P. Heterogeneous Growth in Fishes: Some New Data of Nile Tilapia Oreochromis niloticus and a General View about the Causal Mechanisms. Bol. Fisiol. Anim. 1989, 13, 7-22.

35. Volpato, G.L.; Fernandes, M.O. Social Control of Growth in Fish. Braz. J. Med. Biol. Res. 1994, 27, 797-810.

36. Carrieri, M.P.; Volpato, G.L. Does Snatching Frequency Really Indicate Food Ingestion in the Nile Tilapia? Physiol. Behav. 1991, 50, 489-492. [CrossRef]

37. Fernandes, M.O.; Volpato, G.L. Heterogeneous Growth in the Nile Tilapia: Social Stress and Carbohydrate Metabolism. Physiol. Behav. 1993, 54, 319-323. [CrossRef]

38. Enquist, M.; Leimar, O. Evolution of Fighting Behaviour: Decision Rules and Assessment of Relative Strength. J. Theor. Biol. 1983, 102, 387-410. [CrossRef]

39. Nelissen, M.H.J. Does Body Size Affect the Ranking of a Cichild Fish in a Dominance Hierarchy? J. Ethol. 1992, 10, 153-156. [CrossRef]

40. Beeching, S.C. Visual Assessment of Relative Body Size in a Cichlid Fish, the Oscar, Astronotus ocellatus. Ethology 1992, 90, 177-186. [CrossRef]

41. Enquist, M.; Ljungberg, T.; Zandor, A. Visual Assessment of Fighting Ability in the Cichlid Fish Nannacara anomala. Anim. Behav. 1987, 35, 1262-1264. [CrossRef]

42. Slavík, O.; Pešta, M.; Horký, P. Effect of Grading on Energy Consumption in European Catfish Silurus Glanis. Aquaculture 2011, 313, 73-78. [CrossRef]

43. Boscolo, C.N.P.; Morais, R.N.; Gonçalves-de-Freitas, E. Same-Sized Fish Groups Increase Aggressive Interaction of Sex-Reversed Males Nile Tilapia GIFT Strain. Appl. Anim. Behav. Sci. 2011, 135, 154-159. [CrossRef]

44. Barreto, T.N.; Boscolo, C.N.P.; Gonçalves-de-Freitas, E. Homogeneously Sized Groups Increase Aggressive Interaction and Affect Social Stress in Thai Strain Nile Tilapia (Oreochromis niloticus). Mar. Freshw. Behav. Physiol. 2015, 48, 309-318. [CrossRef]

45. Garcia, F.; Romera, D.M.; Gozi, K.S.; Onaka, E.M.; Fonseca, F.S.; Schalch, S.H.C.; Candeira, P.G.; Guerra, L.O.M.; Carmo, F.J.; Carneiro, D.J.; et al. Stocking Density of Nile Tilapia in Cages Placed in a Hydroelectric Reservoir. Aquaculture 2013, 410-411, 51-56. [CrossRef]

46. Ellis, T.; North, B.; Scott, A.P.; Bromage, N.R.; Porter, M.; Gadd, D. The Relationships between Stocking Density and Welfare in Farmed Rainbow Trout. J. Fish Biol. 2002, 61, 493-531. [CrossRef]

47. Adams, C.E.; Turnbull, J.F.; Bell, A.; Bron, J.E.; Huntingford, F.A. Multiple Determinants of Welfare in Farmed Fish: Stocking Density, Disturbance, and Aggression in Atlantic Salmon (Salmo salar). Can. J. Fish. Aquat. Sci. 2007, 64, 336-344. [CrossRef] 
48. Ellison, A.R.; Uren Webster, T.M.; Rey, O.; Garcia de Leaniz, C.; Consuegra, S.; Orozco-terWengel, P.; Cable, J. Transcriptomic Response to Parasite Infection in Nile Tilapia (Oreochromis niloticus) Depends on Rearing Density. BMC Genom. 2018, 19, 723. [CrossRef]

49. Barcellos, L.J.G.; Nicolaiewsky, S.; De Souza, S.M.G.; Lulhier, F. Plasmatic Levels of Cortisol in the Response to Acute Stress in Nile Tilapia, Oreochromis niloticus (L.), Previously Exposed to Chronic Stress. Aquac. Res. 1999, 30, 437-444. [CrossRef]

50. Maruska, K.P.; Fernald, R.D. Contextual Chemosensory Urine Signaling in an African Cichlid Fish. J. Exp. Biol. 2012. [CrossRef] [PubMed]

51. Almeida, O.G. Urine as a Social Signal in the Mozambique Tilapia (Oreochromis mossambicus). Chem. Senses 2005, 30 (Suppl. 1), i309-i310. [CrossRef] [PubMed]

52. Barata, E.N.; Hubbard, P.C.; Almeida, O.G.; Miranda, A.; Canário, A.V. Male Urine Signals Social Rank in the Mozambique Tilapia (Oreochromis mossambicus). BMC Biol. 2007, 5, 54. [CrossRef] [PubMed]

53. Keller-Costa, T.; Saraiva, J.L.; Hubbard, P.C.; Barata, E.N.; Canário, A.V.M. A Multi-Component Pheromone in the Urine of Dominant Male Tilapia (Oreochromis mossambicus) Reduces Aggression in Rivals. J. Chem. Ecol. 2016, 42, 173-182. [CrossRef]

54. Lopes, A.C.C.; Villacorta-Correa, M.A.; Carvalho, T.B. Lower Light Intensity Reduces Larval Aggression in Matrinxã, Brycon amazonicus. Behav. Process. 2018, 151, 62-66. [CrossRef] [PubMed]

55. Gonçalves-de-Freitas, E.; Carvalho, T.B.; Oliveira, R.F. Photoperiod Modulation of Aggressive Behavior Is Independent of Androgens in a Tropical Cichlid Fish. Gen. Comp. Endocrinol. 2014, 207, 41-49. [CrossRef]

56. Walton, J.C.; Weil, Z.M.; Nelson, R.J. Influence of Photoperiod on Hormones, Behavior, and Immune Function. Front. Neuroendocrinol. 2011, 32, 303-319. [CrossRef] [PubMed]

57. Munro, A.D. Effects of Melatonin, Serotonin, and Naloxone on Aggression in Isolated Cichlid Fish (Aequidens pulcher). J. Pineal Res. 1986, 3, 257-262. [CrossRef] [PubMed]

58. Jasnow, A.M.; Huhman, K.L.; Bartness, T.J.; Demas, G.E. Short Days and Exogenous Melatonin Increase Aggression of Male Syrian Hamsters (Mesocricetus auratus). Horm. Behav. 2002, 42, 13-20. [CrossRef]

59. Larson, E.T.; Winberg, S.; Mayer, I.; Lepage, O.; Summers, C.H.; Øverli, Ø. Social Stress Affects Circulating Melatonin Levels in Rainbow Trout. Gen. Comp. Endocrinol. 2004, 136, 322-327. [CrossRef] [PubMed]

60. Munley, K.M.; Rendon, N.M.; Demas, G.E. Neural Androgen Synthesis and Aggression: Insights From a Seasonally Breeding Rodent. Front. Endocrinol. (Lausanne) 2018, 9. [CrossRef]

61. Castro, A.L.S.; Gonçalves-de-freitas, E.; Volpato, G.L.; Oliveira, C. Visual Communication Stimulates Reproduction in Nile Tilapia, Oreochromis niloticus (L.). Braz. J. Med. Biol. Res. 2009, 42, 368-374. [CrossRef] [PubMed]

62. do Nascimento Falsarella, L.; Brandão, M.L.; Gonçalves-de-Freitas, E. Fish Adjust Aggressive Behavior to Audience Size with Limited Information on Bystanders' Fighting Ability. Behav. Process. 2017, 142, 116-118. [CrossRef]

63. Carvalho, T.B.; Ha, J.C.; Gonçalves-de-Freitas, E. Light Intensity Can Trigger Different Agonistic Responses in Juveniles of Three Cichlid Species. Mar. Freshw. Behav. Physiol. 2012, 45, 91-100. [CrossRef]

64. Carvalho, T.B.; Mendonça, F.Z.; Costa-Ferreira, R.S.; Gonçalves-de-Freitas, E. The Effect of Increased Light Intensity on the Aggressive Behavior of the Nile Tilapia, Oreochromis niloticus (Teleostei: Cichlidae). Zoologia 2013, 30, 125-129. [CrossRef]

65. Fiszbein, A.; Cánepa, M.; Vázquez, G.R.; Maggese, C.; Pandolfi, M. Photoperiodic Modulation of Reproductive Physiology and Behaviour in the Cichlid Fish Cichlasoma dimerus. Physiol. Behav. 2010, 99, 425-432. [CrossRef] [PubMed]

66. Martinez-Chavez, C.C.; Al-Khamees, S.; Campos-Mendoza, A.; Penman, D.J.; Migaud, H. Clock-Controlled Endogenous Melatonin Rhythms in Nile Tilapia (Oreochromis niloticus niloticus) and African Catfish (Clarias gariepinus). Chronobiol. Int. 2008, 25, 31-49. [CrossRef]

67. El-Sayed, A.-F.M.; Kawanna, M. Effects of Photoperiod on Growth and Spawning Efficiency of Nile Tilapia (Oreochromis niloticus L.) Broodstock in a Recycling System. Aquac. Res. 2007, 38, 1242-1247. [CrossRef]

68. Newberry, R.C. Environmental Enrichment: Increasing the Biological Relevance of Captive Environments. Appl. Anim. Behav. Sci. 1995, 44, 229-243. [CrossRef]

69. Mason, G.; Clubb, R.; Latham, N.; Vickery, S. Why and How Should We Use Environmental Enrichment to Tackle Stereotypic Behaviour? Appl. Anim. Behav. Sci. 2007, 102, 163-188. [CrossRef] 
70. van de Weerd, H.A.; Day, J.E.L. A Review of Environmental Enrichment for Pigs Housed in Intensive Housing Systems. Appl. Anim. Behav. Sci. 2009, 116, 1-20. [CrossRef]

71. Salvanes, A.G.V.; Braithwaite, V.A. Exposure to Variable Spatial Information in the Early Rearing Environment Generates Asymmetries in Social Interactions in Cod (Gadus morhua). Behav. Ecol. Sociobiol. 2005, 59, 250-257. [CrossRef]

72. Salvanes, A.G.V.; Braithwaite, V.A. The Need to Understand the Behaviour of Fish Reared for Mariculture or Restocking. ICES J. Mar. Sci. 2006, 63, 346-354. [CrossRef]

73. Salvanes, A.G.V.; Moberg, O.; Ebbesson, L.O.E.; Nilsen, T.O.; Jensen, K.H.; Braithwaite, V. a. Environmental Enrichment Promotes Neural Plasticity and Cognitive Ability in Fish. Proc. Biol. Sci. 2013, 280, 20131331. [CrossRef]

74. Basquill, S.P.; Grant, J.W.A. An Increase in Habitat Complexity Reduces Aggression and Monopolization of Food by Zebra Fish (Danio Rerio); Prentice Hall Inc.: Upper Saddle River, NJ, USA, 1997; Volume 98.

75. Barley, A.J.; Coleman, R.M. Habitat Structure Directly Affects Aggression in Convict Cichlids Archocentrus nigrofasciatus. Curr. Zool. 2010, 56, 52-56.

76. Kadry, V.O.; Barreto, R.E. Environmental Enrichment Reduces Aggression of Pearl Cichlid, Geophagus brasiliensis, during Resident-Intruder Interactions. Neotrop. Ichthyol. 2010, 8, 329-332. [CrossRef]

77. Torrezani, C.S.; Pinho-Neto, C.F.; Miyai, C.A.; Sanches, F.H.C.; Barreto, R.E. Structural Enrichment Reduces Aggression in Tilapia rendalli. Mar. Freshw. Behav. Physiol. 2013, 46, 183-190. [CrossRef]

78. Barreto, R.E.; Carvalho, G.G.A.; Volpato, G.L. The Aggressive Behavior of Nile Tilapia Introduced into Novel Environments with Variation in Enrichment. Zoology 2011, 114, 53-57. [CrossRef] [PubMed]

79. Arnott, G.; Elwood, R.W. Information Gathering and Decision Making about Resource Value in Animal Contests. Anim. Behav. 2008, 76, 529-542. [CrossRef]

80. Dunbar, R.I.M. The Social Role of Touch in Humans and Primates: Behavioural Function and Neurobiological Mechanisms. Neurosci. Biobehav. Rev. 2010, 34, 260-268. [CrossRef]

81. Soares, M.C.; Oliveira, R.F.; Ros, A.F.H.; Grutter, A.S.; Bshary, R. Tactile Stimulation Lowers Stress in Fish. Nat. Commun. 2011, 2, 534. [CrossRef] [PubMed]

82. Bolognesi, M.C.; dos Santos Gauy, A.C.; Gonçalves-de-Freitas, E. Tactile Stimulation Reduces Aggressiveness but Does Not Lower Stress in a Territorial Fish. Sci. Rep. 2019, 9, 40. [CrossRef] [PubMed]

83. Tallet, C.; Sy, K.; Prunier, A.; Nowak, R.; Boissy, A.; Boivin, X. Behavioural and Physiological Reactions of Piglets to Gentle Tactile Interactions Vary According to Their Previous Experience with Humans. Livest. Sci. 2014, 167, 331-341. [CrossRef]

84. Schmied, C.; Waiblinger, S.; Scharl, T.; Leisch, F.; Boivin, X. Stroking of Different Body Regions by a Human: Effects on Behaviour and Heart Rate of Dairy Cows. Appl. Anim. Behav. Sci. 2008, 109, 25-38. [CrossRef]

85. Clotfelter, E.D.; O'Hare, E.P.; McNitt, M.M.; Carpenter, R.E.; Summers, C.H. Serotonin Decreases Aggression via 5-HT1A Receptors in the Fighting Fish Betta splendens. Pharmacol. Biochem. Behav. 2007, 87, 222-231. [CrossRef]

86. Zubizarreta, L.; Perrone, R.; Stoddard, P.K.; Costa, G.; Silva, A.C. Differential Serotonergic Modulation of Two Types of Aggression in Weakly Electric Fish. Front. Behav. Neurosci. 2012, 6, 1-10. [CrossRef] [PubMed]

87. Sabbah, S.; Laria, R.; Gray, S.M.; Hawryshyn, C.W. Functional Diversity in the Color Vision of Cichlid Fishes. BMC Biol. 2010, 8, 133. [CrossRef]

88. Hofmann, C.M.; O'Quin, K.E.; Justin Marshall, N.; Cronin, T.W.; Seehausen, O.; Carleton, K.L. The Eyes Have It: Regulatory and Structural Changes Both Underlie Cichlid Visual Pigment Diversity. PLoS Biol. 2009, 7. [CrossRef] [PubMed]

89. Maia, C.M.; Volpato, G.L. Preference Index Supported by Motivation Tests in Nile Tilapia. PLoS ONE 2017, 12, e0175821. [CrossRef]

90. Torres, I.F.A.; da Silva Ferreira, A.; de Souza e Silva, W.; Mesquita, F.O.; Luz, R.K. Effect of Environmental Color on Learning of Nile Tilapia. Appl. Anim. Behav. Sci. 2018, 209, 104-108. [CrossRef]

91. Maia, C.M.; Volpato, G.L. Environmental Light Color Affects the Stress Response of Nile Tilapia. Zoology 2013, 116, 64-66. [CrossRef] [PubMed]

92. Volpato, G.L.; Bovi, T.S.; de Freitas, R.H.A.; da Silva, D.F.; Delicio, H.C.; Giaquinto, P.C.; Barreto, R.E. Red Light Stimulates Feeding Motivation in Fish but Does Not Improve Growth. PLoS ONE 2013, 8, e59134. [CrossRef] [PubMed] 
93. Volpato, G.L.; Duarte, C.R.A.; Luchiari, A.C. Environmental Color Affects Nile Tilapia Reproduction. Braz. J. Med. Biol. Res. 2004, 37, 479-483. [CrossRef] [PubMed]

94. Volpato, G.L.; Barreto, R.E. Environmental Blue Light Prevents Stress in the Fish Nile Tilapia. Braz. J. Med. Biol. Res. 2001, 34, 1041-1045. [CrossRef] [PubMed]

95. Volpato, G.; Gonçalves-de-Freitas, E.; Fernandes-de-Castilho, M. Insights into the Concept of Fish Welfare. Dis. Aquat. Organ. 2007, 75, 165-171. [CrossRef] [PubMed]

96. Dawkins, M.S. The Science of Animal Suffering. Ethology 2008, 114, 937-945. [CrossRef]

97. Volpato, G.L. Challenges in Assessing Fish Welfare. ILAR J. 2009, 50, 329-337. [CrossRef] [PubMed]

98. Luchiari, A.C.; do Amaral Duarte, C.R.; de Morais Freire, F.A.; Nissinen, K. Hierarchical Status and Colour Preference in Nile Tilapia (Oreochromis niloticus). J. Ethol. 2007, 25, 169-175. [CrossRef]

99. Maia, C.M.; Volpato, G.L. A History-Based Method to Estimate Animal Preference. Sci. Rep. 2016, 6, 28328. [CrossRef] [PubMed]

100. Mendonça, F.Z.; Volpato, G.L.; Costa-Ferreira, R.S.; Gonçalves-de-Freitas, E. Substratum Choice for Nesting in Male Nile Tilapia Oreochromis niloticus. J. Fish Biol. 2010, 77, 1439-1445. [CrossRef] [PubMed]

101. Freitas, R.H.A.; Volpato, G.L. Motivation and Time of Day Affect Decision-Making for Substratum Granulometry in the Nile Tilapia Oreochromis niloticus. J. Appl. Ichthyol. 2013, 29, 239-241. [CrossRef]

(c) 2019 by the authors. Licensee MDPI, Basel, Switzerland. This article is an open access article distributed under the terms and conditions of the Creative Commons Attribution (CC BY) license (http:/ / creativecommons.org/licenses/by/4.0/). 